\title{
Pacific insights into the Rainbow Warrior legacy
}

MICHAEL SERGEL is a journalist with NZME who reported on the 30th anniversary of the Rainbow Warrior bombing.

Eyes of Fire: The Last Voyage of the Rainbow Warrior, by David Robie. [30th Anniversary Ed.] Auckland: Little Island Press, 2015, 194 pp. ISBN 978-1-877484-28-5

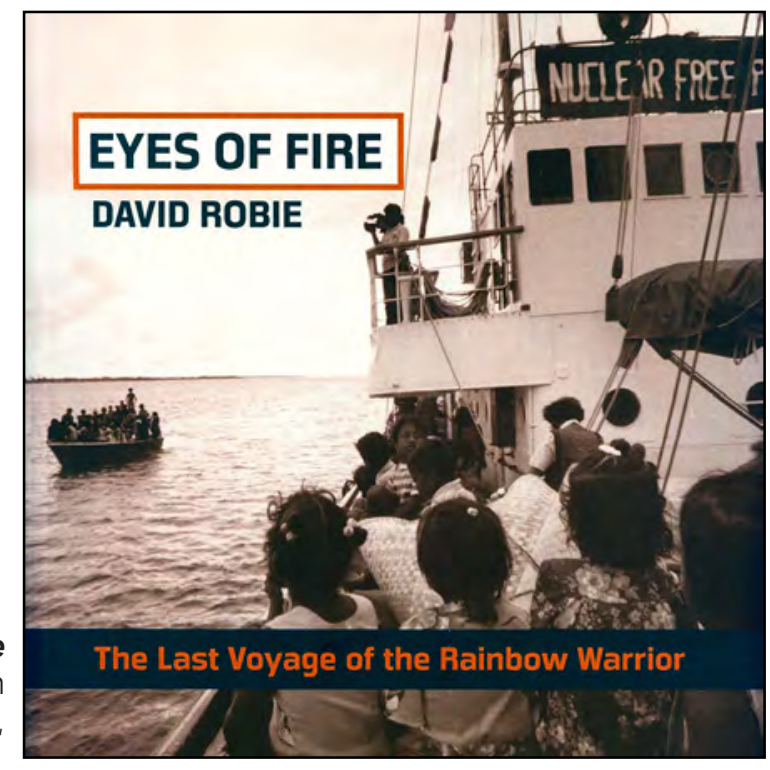

$\mathrm{T}^{\mathrm{H}}$ HE 1985 bombing of the Rainbow Warrior is often remembered as the deadly consequence of a small Pacific nation taking a defiant stance against nuclear testing by major powers. Thirty years on, the updated edition of David Robie's Eyes of Fire moves beyond the David and Goliath narrative that puts New Zealand at the centre of the story.

Prime Minister David Lange called the bombing a 'sordid act of international statebacked terrorism' and an 'unprecedented affront to sovereignty' (p. 128). Months earlier, he had defended New Zealand's anti-nuclear position at the Oxford Union. Years later, he said the lack of international support had only strenthened the country's resolve (Young, 2005).

But Robie reminds us the bombing was far more than a key date on New Zealand's political timeline. The former British fishing trawler had been part of missions to

stop whalers, sealers and nuclear warships in Scotland, Ireland, France, Spain, the United States and Peru. It had even been at the centre of a diplomatic Cold War clash during a visit to Siberia.

Eyes of Fire starts with the very beginning of Greenpeace - the 'floating farmhouse' of Canadian ecologists, lawyers, journalists and hippies who sailed out to stop a five-megaton nuclear test at Amchitka in the North Pacific in 1971 (p. 1). It presents a movement so diverse its supporters could not even agree if the Pacific should be nuclear-free.

Robie covers the confrontations between Greenpeace boats and French authorities in 1972 and 1973 and the legal action by New Zealand that forced France to abandon above-ground atmospheric testing at Moruroa Atoll. Later, he covers the flotilla the Rainbow Warrior was supposed to lead against France's underground nuclear testing in 1985. 
But the main focus of Eyes of Fire is the observations Robie made during his time on board the Warrior on its final Pacific voyage from Jacksonville to Auckland and 'Operation Exodus' in the Marshall Islands. As deckhand Grace O'Sullivan jokingly put it, the ship became 'the Greenpeace Atoll Cinemas, as well as the Rainbow Warrior Furniture Removals and the evacuationeducation-and-entertainment team' (p. 87).

What began as an environmental publicity campaign through the Pacific to gain support for the anti-nuclear movement became a humanitarian mission to evacuate the people of the Rongelap Atoll, who were still suffering from the effects of radiation from Castle Bravo tests three decades earlier in March 1954.

The bomb was the largest nuclear device ever detonated by the United States, and the culmination of an eight-year testing programme at Bikini Atoll following on from World War II. The people of Bikini had already been asked to temporarily evacuate for the 'good of mankind' in 1946 and have never been able to return (Weisgall, 1980).

The ash from the Castle Bravo bomb spread to Rongelap, where it fell on homes and contaminated water supplies. Rongelap mayor John Anjain recollected how 'some people put it in their mouths ... one man rubbed it in his eye ... people walked in it... children played in it', but everyone was oblivious to what it was or what dangers it posed (p. 21).

The islanders were evacuated by US officials three days later, suffering burns, hair loss and radiation sickness. Three years later the US deemed it safe to return. But when the Rainbow Warrior arrived three decades later, Robie said the islanders who had returned were facing nightmare-high rates of cancer, miscarriages and boneless 'jellyfish' babies.

One man who had already left the island said the detonation of Castle Bravo was an act of murder and living on the island was a death sentence (p. 52). Australian filmmaker Dennis O'Rourke said the US was aware of the risk to the atoll when it detonated the bomb, and used the outcome as a test case for the effect of radiation on people (p. 52).

Many writers have described how displacement forces people to move from one set of dangers to a whole new set of problems-whether it be mass migration of Jewish people after the Holocaust (Warhaftig, 1946), the violent partition of South Asia (Butalia, 1998), or the evacuation of the Carteret Islands due to sea level rise (Edwards, 2013). (Robie takes up the issue of climate change refugees in his other recent book on Pacific human rights, Don't Spoil My Beautiful Face).

This idea also shows up in Robie's first-hand account of the relocation. The Rongelap Islanders deeply regetted leaving their homeland, and left their church 'padlocked and shuttered, waiting for the day when [they] might be able to return' (p. 67). But they also left with a sense of urgency, worried about their children being exposed to further radiation.

The Rongelap people relocated to Mejato on Kwajalein Atoll, where they were safe from radiation but faced severe food shortages and had to rebuild their homes. Many pregnant women and children were 
taken on to nearby Ebeye Island for medical attention from the 'overtaxed, understaffed local hospital' - an island where many Rongelap people already lived (p. 69).

Ebeye faced many of its own problems after the United States militiary moved thousands of islanders there to make way for the Kwajalein Missile Range. Robie describes it as a 'plywood shanty island' and the 'ghetto of the Pacific'-crowded and poor because of United States military testing but economically dependent on it at the same time (p. 71).

The US downplayed the effect of radiation on Rongelap and the need for evacuation. One American official said there was no radiological or medical reason for the islanders to move (p. 45). Another said the evacuation had been 'instigated by outsiders who misled the islanders', and the islanders had been 'tragically... victimised' (pp. 67-68).

Robie claims anti-nuclear and independence movements were also falsely accused of having Soviet ties. On one occasion he says, US researcher Dr Glenn Alcalay, on board for part of the voyage, was contacted by the FBI and accused of Soviet loyalties after a casual meeting with a Soviet embassy secretary (p. 71). On another, he says Greenpeace faced accusations of Soviet links in Kiribati (p. 81).

Vanuatu and New Zealand were also ostracised for their anti-nuclear positions. Robie recounts a security guard on the US base on Kwajelein Island who told him New Zealand had 'gone all commie' by banning US nuclear ships, and the Marshall Islands was lucky the US was saving it from 'commie' invasion and interference (p. 75).
New Zealand may associate the Rainbow Warrior with one unjustified bombing and one tragic death, but the ship sailed the Pacific to raise awareness of many bombs and many deaths. Robie hopes new research and compensation claims will force super powers to not make the mistakes of the past. But to do that, they will need to accept they made mistakes in the first place.

\section{References}

Butalia, U. (1998). The other side of silence: Voices from the partition of India. New Delhi: Penguin Books India.

Edwards, J. B. (2013). The logistics of climateinduced resettlement: Lessons from the Carteret Islands, Papua New Guinea. Refugee Survey Quarterly, 32(3), 52-78.

Robie, D. (2014). Don't spoil my beautiful face: Media, mayhem and human rights in the Pacific. Auckland: Little Island Press.

Young, A. (2005, August 16). Interview: David Lange. The New Zealand Herald. Retrieved on August 20, 2015, from www.nzherald. co.nz/rainbow-warrior-bombing/news/article.cfm?c_id $=1500930 \&$ objectid $=3575913$

Weisgall, J. M. (1980). The nuclear nomads of Bikini. Foreign Policy, 74-98.

Warhaftig, Z. (1946). Uprooted: Jewish refugees and displaced persons after liberation. New York: Institute of Jewish Affairs.

\section{Microsite}

Eyes of Fire:30 Years on. (2015) [Microsite]. Auckland:Little Island Press. eyes-of-fire.littleisland.co.nz 